\title{
Asymmetrical leaves induced by water deficit show asym- metric photosynthesis in common bean
}

\author{
Gustavo Maia Souza ${ }^{1 *}$, Juliana de Oliveira Fernandes Viana ${ }^{2}$ and Ricardo Ferraz de Oliveira $^{3}$
}

${ }^{1}$ Laboratório de Ecofisiologia Vegetal, Universidade do Oeste Paulista, Campus II, Rodovia Raposo Tavares km 572, CEP 19067-175, Presidente Prudente, SP, Brasil; '2Departamento de Ciências Florestais, Universidade de São Paulo ESALQ-USP, CP 09, 13418-900, Piracicaba, SP, Brasil. ${ }^{3}$ Departamento de Ciências Biológicas, Universidade de São Paulo ESALQ-USP, CP 09, 13418-900, Piracicaba, SP, Brasil. *Corresponding author: gumaia@universiabrasil.net

Received: 05/04/2005, Accepted: 17/06/2005

In this study we tested the hypothesis that leaf asymmetric growth induced by water deficit in common bean (Phaseolus vulgaris L.) might be correlated with different net photosynthesis rates between the two opposed leaflets (right and left) considering a bilateral symmetric plane. In order to induce developmental instability, the drought-sensitive common bean genotype "Jalo Precoce" was subjected to periods of suspended irrigation during its vegetative growth. Developmental instability was evaluated by measurements of leaflets asymmetry, and the effects of drought on gas exchanges were taken in both symmetrical leaflets (right and left) in relation to the central leaflet. Water deficit induced an increase of $80 \%$ in leaf asymmetry. Net photosynthesis of $P$. vulgaris was affected by water deficit in two ways, reducing its physiological yield and increasing its variability between leaflets. Thus, as we hypothesized, the increase in developmental instability, measured by leaf symmetry deviations, was supported by a variable net photosynthesis distribution in the leaves induced by drought.

Key words: developmental instability, leaf symmetry, water deficit.

Folhas assimétricas em feijoeiro sob deficiência hídrica exibem fotossíntese assimétrica: Neste estudo, propomos testar a hipótese de que um crescimento foliar assimétrico induzido por deficiência hídrica em feijoeiro (Phaseolus vulgaris L.) pode estar relacionado com diferentes taxas de fotossíntese líquida entre dois folíolos opostos (direito e esquerdo), considerando um plano de simetria bilateral. Dessa forma, para testar tal hipótese, o genótipo Jalo Precoce, sensível à deficiência hídrica, foi submetido a períodos de suspensão da irrigação em seu estado vegetativo para indução de instabilidade em seu desenvolvimento. Avaliou-se a estabilidade do desenvolvimento das plantas pelo uso de medidas de assimetria entre ambos os folíolos esquerdo e direito, e os efeitos da seca sobre as trocas gasosas nos mesmos folíolos, em relação ao folíolo central. A deficiência hídrica induziu um aumento de $80 \%$ na assimetria foliar. A fotossíntese foi afetada de duas formas: uma redução em seus níveis fisiológicos e um aumento na variabilidade entre os folíolos direito e esquerdo. Assim, como foi proposto na hipótese inicial, o aumento da instabilidade do desenvolvimento, medido pelos desvios de simetria foliar, deve ter sido influenciado diretamente pela variabilidade das taxas fotossintéticas entre os folíolos.

Palavras-chave: deficiência hídrica, instabilidade do desenvolvimento, simetria foliar.

\section{INTRODUCTION}

Measures of environmental change effects on plant physiology may be divided into in two categories, 1) instantaneous physiological measures, such as gas exchanges or chlorophyll $a$ fluorescence, and 2) integrative physiological measures over larger temporal scales, such as growth, productivity and, more recently, developmental instability (Llorens et al., 2002).
Developmental stability is based on the organisms' ability to minimize random perturbations during development and is often used as a measurement of the effects of environmental perturbations, such as drought, on organisms (Freeman et al., 1993; Graham, et al., 1993; Møller and Swaddle, 1997).

Fluctuating asymmetry (FA) is widely used in developmental instability studies (Graham et al., 1993; Møller and 
Swaddle, 1997; Cowart and Graham, 1999). An individual unable to buffer random disturbances on its development, either genetic or environmental in origin, may exhibit slight deviations from perfect symmetry in organs with, a priori, bilateral symmetry, such as leaves with central veins. Such deviations are termed fluctuating asymmetry when they are nondirectional and random (Palmer and Strobeck, 1986; Møller and Swaddle, 1997). Accordingly, more symmetric individuals have greater developmental stability and usually exhibit greater reproductive success, and better survival rates than asymmetric individuals (Freeman et al., 1993). According to Rettig et al. (1997) measures of developmental instability such as FA may provide a more sensitive indicator of stress than traditional measures (e.g. growth, survival) because FA has a measurable response at a lower threshold of stress.

Water deficit is an environmental perturbation that could induce increase in plant developmental instability (Escós et al., 2000; Otronen and Roselund, 2001; Llorens et al., 2002; Souza et al., 2004a), inducing asymmetric growth in leaves. Cellular growth is one of the physiological processes with higher sensitivity to water deficit, decreasing the enlargement rate and, consequently, the leaf area (Nilsen and Orcutt, 1996). Moreover, even mild drought conditions could constrain the photosynthetic process and transpiration rate due to decreasing cell turgor, stomatal closing, and the decreasing of intercellular $\mathrm{CO}_{2}$ diffusion (Chaves, 1991; Cornic, 2000; Flexas et al.; 2004).

Since photosynthesis is a primary process related to plant growth, providing nearly all of the raw material for growth (Farquhar and Sharkey, 1994), it is suggested that higher developmental instability, such as higher leaf FA, might be correlated with asymmetric net photosynthetic rates between opposite leaf sides (right and left). Llorens et al. (2002) studying developmental instability of a heathland shrub subjected to experimental drought and warming, showed that leaf FA was a more sensitive indicator of physiological disturbances than leaf size or gas exchange measurements. However, this study did not investigate the relationship between leaf asymmetric growth and different photosynthetic rates in opposite leaf sides, considering a plane of bilateral symmetry (e.g., right and left leaf sides in relation to the central vein).

In this study we tested the hypothesis that leaf asymmetric growth induced by water deficit in common bean (Phaseolus vulgaris L.) may be correlated with different net photosynthetic rates between the two sides of leaflets considering a plane of bilateral symmetry. In order to induce FA, the drought-sensitive common bean genotype "Jalo Precoce" (Souza et al., 2003) was subjected to periods of suspended irrigation during its vegetative growth. Developmental instability was evaluated by measurements of leaflets asymmetry (Souza et al., 2004a), and the effects of drought on gas exchanges were taken in both symmetrical leaflets (right and left) in relation to the central leaflet. Thus, we expected that plants subjected to water deficit would exhibit asymmetrical growth and asymmetric photosynthesis between right and left leaflets compared to control plants (i.e. plants continuously irrigated).

\section{MATERIAL AND METHODS}

Seeds of $P$. vulgaris were germinated in plastic pots containing $6 \mathrm{~kg}$ of a mixture of organic substrate (Plantmax, Eucatex-agro) and white silica (2:1). All plants received 500 $\mathrm{mL}$ of modified Hoagland solution (McCree, 1986) at the $22^{\text {nd }}$ day after germination. The experiment was performed under greenhouse conditions from January to February 2004, at Piracicaba, SP, Brazil $\left(22^{\circ} 42^{\prime} \mathrm{S}, 4^{\circ} 38^{\prime} \mathrm{W}\right)$. The plants were divided randomly into two treatments: Control plants (irrigated every 2 days), and water-stressed plants (with two periods of suspended irrigation of 13 and 10 days, with one intermediate watering). For each treatment, 10 replicates were used.

At the end of the $33^{\text {rd }}$ day of growth, measurements of the width in the widest part of the right and left leaflets were taken using a Mitutoyo digital caliper $( \pm 0.01 \mathrm{~mm})$ in the last two youngest totally expanded leaves of each plant. The symmetry deviations were considered as the width differences (R-L) among linear segments in the widest area of right $(\mathrm{R})$ and left $(\mathrm{L})$ leaflets.

For the asymmetry analysis the data were transformed according to Cowart and Graham (1999). The symmetry deviations (d) were calculated in the general way as: $d$ $=\log \mathrm{x}-\log \mathrm{x}^{\prime}$. This transformation removes mistakes related to the differences in size scales. Asymmetry measures of leaves, as a measure of the absolute value $d$, were normalized using a Box-Cox transformation. The transformation $\mathrm{d}^{*}=(|\mathrm{d}|+0.00005)^{0.33}$ works well for the normalization of asymmetric data (Freeman et al., 1999).

The symmetry deviations (d), which where significantly higher in water-stressed plants than in control plants, were caused by the imposed water deficit, indicating developmental instability during the development of the plants. Although there are multiple other parameters to estimate developmental 
instability (Palmer and Strobeck, 1986; Palmer, 1994), in the present report, we chose $\mathrm{d}$ as the asymmetry measure, because it is a simple and accessible measurement that provides a suitable and reliable parameter for asymmetry analysis (Cowart and Graham, 1999). Moreover, this study is not a classical study on fluctuating asymmetry, but it rather proposes to integrate two different physiological measurements in order to improve the understanding about plant responses to environmental disturbances.

Before proceeding with the fluctuating asymmetry analysis, we followed the suggestion of Palmer (1994) and Cowart and Graham (1999) to verify the occurrence of directional asymmetry. Directional asymmetry, which is a genetic based trend to develop one side of a trait more than the other, is mostly an adaptive and functional asymmetry rather than an indicative of developmental stability under environmental changes (noise) such as fluctuating asymmetry. A one-sample t-test $(\mathrm{p}<0.05)$ was used to test whether mean values of right-minus-left values differd significantly from zero.

Leaf water potential $\left(\psi_{\mathrm{w}}\right)$ of control and water-stressed plants was measured in periods of 3 days by the dew point method, using a microvoltimeter (HR-33T, Wescor, Logan, USA) coupled to the sampling chamber (C-52, Wescor, Logan, USA).

The measurements of gas exchanges in the right and left leaflets were taken in three mature and totally expanded leaves randomly chosen in each water regime. The measurements in both leaflets were taken simultaneously using two Infra Red Gas Analyzers (model LI-6400, Li-Cor, Lincoln, USA). The measurements of net $\mathrm{CO}_{2}$ assimilation $\left(\mathrm{A}, \mu \mathrm{mol} \mathrm{CO} \mathrm{CO}^{-2} \cdot \mathrm{s}^{-1}\right)$, stomatal conductance ( $\mathrm{gs}$, mol $\left.\mathrm{H}_{2} \mathrm{O} \cdot \mathrm{m}^{-2} \cdot \mathrm{s}^{-1}\right)$, transpiration (E, mmol $\mathrm{H}_{2} \mathrm{O} \cdot \mathrm{m}^{-2} \cdot \mathrm{s}^{-1}$ ) and intercellular $\mathrm{CO}_{2}$ concentration $\left(\mathrm{Ci}, \mu \mathrm{mol} . \mathrm{mol}^{-1}\right)$ were recorded every $10 \mathrm{~s}$ during $15 \mathrm{~min}$, following protocol of acquisition of gas exchanges time series developed by Souza et al. (2004c). The water use efficiency [WUE, $\mu \mathrm{mol} \mathrm{CO}_{2} \cdot\left(\mathrm{mmol} \mathrm{H}_{2} \mathrm{O}\right)^{-1}$ ] is the result of A normalized by E.

The measurements were recorded under laboratory conditions and the environmental sample cuvete of the LI6400 was maintained constant throughout the measurements with $30^{\circ} \mathrm{C}$ of temperature, $800 \mu \mathrm{mol} \cdot \mathrm{m}^{-2} \cdot \mathrm{s}^{-1}$ of PAR (photosynthetic active radiation), and $370 \mathrm{ppm}$ of $\mathrm{CO}_{2}$. The leaf-to-air vapor pressure difference was $1 \mathrm{kPa}$ maintained by a dew point generator (Li-610, Li-Cor, Lincoln, USA) attached to LI-6400. Before scoring the measurements, plants were moved to laboratory and placed under environmental measurements conditions until gas exchange stabilization. The photosynthesis deviations between right (Ar) and left (Al) leaflets were calculated as the differences between net $\mathrm{CO}_{2}$ assimilations measures between both leaflets $(\mathrm{Ar}-\mathrm{Al})$.

For the comparison of asymmetry averages and gas exchanges parameters between the control plants and the plants under water deficit, one way variance analyses (ANOVA, $\mathrm{p}<0.05$ ) were carried out.

\section{RESULTS AND DISCUSSION}

Effects of water deficit on gas exchanges: Leaf water potential measured under control and drought conditions were significantly different $(\mathrm{p}<0.05)$ and averaged, respectively, $-0.5 \mathrm{MPa}$ and $-1.1 \mathrm{MPa}$.

Decreasing water potential also significantly affected $(\mathrm{p}<0.05)$ net $\mathrm{CO}_{2}$ assimilation $(\mathrm{A})$, stomatal conductance (gs) and, consequently, transpiration rate (E) (table 1). $\mathrm{CO}_{2}$ intercellular concentration, however, was not affected ( $\mathrm{p}$ $>0.05$ ) by water deficit (table 1). The decreases in A and gs are often shown as normal responses of plants to water deficit (Chaves, 1991; Souza et al., 2003; Flexas et al., 2004). Because partial stomatal closure tends to affect transpiration more than net $\mathrm{CO}_{2}$ assimilation (Nobel, 1999), an increase in water use efficiency (WUE) is an expected response to water stress (Larcher, 1995; Nobel, 1999). In the present study we observed an increase of $77.35 \%$ in WUE in plants under drought conditions (table 1).

The stabilization of $\mathrm{Ci}$ values indicated that availability of $\mathrm{CO}_{2}$ was not a constraining factor responsible for the reduction in A. Therefore, it is likely that water deficit may have directly affected the photosynthetic process. However, such hypothesis must be interpreted with caution because water deficit may lead to unreliable $\mathrm{Ci}$ measures due to patchy stomatal conductance (Kaiser, 1987). Furthermore, the photosynthetic apparatus may be resistant to mild water deficit. In such cases a reduction of $\mathrm{Ci}$ is often observed, caused by gs decreasing, leading to a considerable increase in photorespiration (Cornic et al., 1992; Cornic and Fresneau, 2002).

The leaf water potential values of the plants under water deficit (around -1.1 MPa) and the low gs values suggested that, considering the genotype "Jalo Precoce", the plants were under mild to severe drought (Souza et al., 2003). Moreover, this study was carried out from January to February, which is a typical summer period in tropical and sub-tropical regions with high levels of temperature and irradiance, which could 
cause a synergetic disturbance in the plants. Under these conditions, it is likely that the photosynthetic apparatus might have been damaged by water deficit, decreasing net $\mathrm{CO}_{2}$ assimilation. According to Cornic et al. (1992) leaves with low water potential can lead to a pre-disposition of the photosynthetic apparatus to photoinhibition. Furthermore, plants subjected to mild or severe drought conditions may show damage to the thylakoid membranes affecting electron transport of the Z-scheme (Kaiser, 1987). A straightforward correlation between decreasing stomatal conductance and the yield of the photosystem II has been observed (Medrano et al., 2002; Parry et al., 2002). Water deficit may also cause damage to the biochemical fixation of $\mathrm{CO}_{2}$ in the Calvin cycle decreasing both activation and activity of the ribulose1,5-biphosphate carboxylase/oxygenase (Rubisco), primarily due to the action of inhibitors (Medrano et al., 2002; Parry et al., 2002). The reduction in Rubisco efficiency may be caused by an increase in mesophyllic resistance due to stomatal closure, constraining $\mathrm{CO}_{2}$ uptake into chloroplasts, which could increase the oxygenase action of Rubisco with a consequent increase in photorespiration. Moreover, the ribulose-biphosphate regeneration may also be reduced by drought due to a decrease in ATP synthesis by ATPase. These integrated effects suggest a down-regulation mechanism of the photosynthetic apparatus as a whole affected by water deficit (Medrano et al., 2002).

Effects of water deficiency on leaf symmetry and photosynthesis between right and left leaflets: Leaf deviation from symmetry observed in both water regimes showed a statistical normal distribution as evaluated by the Kolmogorov-Smirnov test (data not shown). Moreover, a one-tailed t-test used to verify the presence of directional asymmetry, supported the presence of fluctuating asymmetry in the character evaluated, instead of directional asymmetry (Cowart and Graham, 1999).

Plants grown under water deficit exhibited $(\mathrm{p}<0.05)$ more asymmetric leaves than plants grown under constant irrigation (table 2). In general, symmetry deviations between the widest parts of the right and left leaflets increased by 80 $\%$ in the leaves developed under water deficit. These results indicate a remarkable effect of drought-induced stress on plant development stability (Llorens et al., 2002).

According to Møller and Swaddle (1997) increases in the variability of cellular growth rates under sub-optimal conditions is a source of developmental instability and it might induce asymmetric growth of plant organs with bilateral symmetry. Furthermore, Souza et al. (2004b,c) have shown that environmental constrains, such as low air humidity and water deficit, tends to induce an increasing irregularity in the dynamics of net photosynthesis, which is a fundamental physiological process related to growth. Therefore, we could suppose that such irregular photosynthetic rates may be a source for asymmetrical growth in P. vulgaris.

The differences in net $\mathrm{CO}_{2}$ assimilation rates between right and left leaflets were also significantly higher $(\mathrm{p}<0.05)$ in plants under water deficit. Deviations of A in plants under drought condition were about $117 \%$ higher than in plants growing under control conditions (table 2).

The results in table 2 showed the same trend between leaf asymmetric growth and differential net photosynthesis between right and left leaflets in P. vulgaris under water deficit. The variability in the net photosynthesis could be caused by patchy stomatal conductance, which is increased under water deficit (Cardon et al., 1994), leading to a nonuniform growth in the leaflets, increasing the leaf asymmetry. These results reinforce the relationship between growth and net photosynthesis, even if some growth analyses do not have photosynthesis at the leaf level as an explicit variable (Farquhar and Sharkey, 1994).

Table 1. Results of gas exchange measurements of $P$. vulgaris plants under water deficit and irrigated conditions. (net $\mathrm{CO}_{2}$ assimilation (A) $\mu \mathrm{mol} \cdot \mathrm{m}^{-2} \cdot \mathrm{s}^{-1}$, transpiration (E) mmol.m ${ }^{2} . \mathrm{s}^{-1}$, intercellular $\mathrm{CO}_{2}$ concentration $(\mathrm{Ci}) \mu \mathrm{mol} . \mathrm{L}^{-1}$ of $\mathrm{CO}_{2}$, stomatal conductance $(\mathrm{gs}) \mathrm{mol} \mathrm{H}_{2} \mathrm{O} \cdot \mathrm{m}^{-2} \cdot \mathrm{s}^{-1}$, water use eficiency (WUE) $=\mathrm{A} / \mathrm{E})$. Statistically significant differences (Tukey test, $\mathrm{p}<0.05$ ) between means in control and water deficit are represented by different superscripts.

\begin{tabular}{cccccc}
\hline & $\mathrm{A}$ & $\mathrm{E}$ & $\mathrm{gs}$ & $\mathrm{Ci}$ & WUE \\
\hline Control & $15.72^{\mathrm{a}}$ & $5.08^{\mathrm{a}}$ & $0.34^{\mathrm{a}}$ & $277.12^{\mathrm{a}}$ & $3.09^{\mathrm{b}}$ \\
Water deficit & $4.88^{\mathrm{b}}$ & $0.89^{\mathrm{b}}$ & $0.05^{\mathrm{b}}$ & $264.89^{\mathrm{a}}$ & $5.48^{\mathrm{a}}$ \\
\hline
\end{tabular}

Table 2. Results of leaf symmetry deviations (LSD) and differences in net photosynthesis (DA) between right and leaf leaflets in plants of the genotype Jalo Precoce (P. vulgaris) under water deficit and irrigated conditions. The values shown below are in a logarithmic scale. Significant differences (Tukey test, $\mathrm{p}<0.05$ ) between means are represented by different superscripts.

\begin{tabular}{ccc}
\hline & DA & LSD \\
\hline Control & $0.041^{\mathrm{b}}$ & $0.020^{\mathrm{b}}$ \\
Water deficit & $0.089^{\mathrm{a}}$ & $0.036^{\mathrm{a}}$ \\
\hline
\end{tabular}


Summarizing, net photosynthesis of $P$. vulgaris was affected by water deficit in two ways, reducing its physiological yield and increasing its variability between leaflets. Thus, as we hypothesize in this study, the increase in developmental instability, as measured by leaf symmetry deviations, is supported by a variable net photosynthesis distribution in the leaves.

Acknowledgements: This study was supported by FAPESP (Fundação de Amparo a Pesquisa no Estado de São Paulo).

\section{REFERENCES}

Cardon ZG, Mott KA, Berry JA (1994) Dynamics of patchy stomatal movements, and their contribution to steady-state and oscillating stomatal conductance calculated using gasexchange techniques. Plant Cell Environ. 17:995-1007.

Chaves MM (1991) Effects of water deficits on carbon assimilation. J. Exp. Bot. 42:1-16.

Cornic G, Fresneau C (2002) Photosynthetic carbon reduction and carbon oxidation cycles are the main electron sinks for photosystem II activity during a mild drought. Ann. Bot. 89:887-894.

Cornic G, Ghashghaie, J, Genty B, Briantais J-M (1992) Leaf photosynthesis is resistant to a mild stress. Photosynthetica 27:295-309.

Cowart NM, Graham JH (1999) Within- and among-individual variation in fluctuating asymmetry of leaves in the fig (Ficus carica L.). Int. J. Plant Sci. 160: 116-121.

Escós J, Alados CL, Pugnaire FI, Puigdefábregas J, Emlen J (2000) Stress resistance strategy in an arid land shrub: interactions between developmental instability and fractal dimension. J. Arid Environ. 45: 325-336.

Farquhar GD, Sharkey TD (1994) Photosynthesis and carbon assimilation. In: Boote KJ, Bennet JM, Sinclair TR, Paulsen GM (eds), Physiology and Determination of Crop Yield, pp.187-210. University of Florida, Gainesville.

Flexas J, Bota J, Loreto F, Cornic G, Sharkey TD (2004) Diffusive and metabolic limitations to photosynthesis under drought and salinity in C3 plants. Plant Biol. 6:269-279.

Freeman DC, Graham JH, Emlen JM (1993) Developmental stability in plants: symmetries, stress, and epigenesis. Genetica 89:97-119.

Freeman DC, Graham JH, Tracy M, Emlen JM, Alados CL (1999) Developmental stability as a means of assessing stress in plants: a case study using electromagnetic fields in soybeans. Int. J. Plant Sci. 160:S157-S166.

Graham, JH, Freeman DC, Emlen JM (1993) Asymmetry, directional asymmetry, and dynamic morphogenesis. Genetica 89:121-137.

Kaiser WM (1987) Effects of water deficit on photosynthetic capacity. Physiol. Plant. 71:142-149.
Larcher W (1995) Physiological plant ecology: ecophysiology and stress physiology of functional groups. Springer-Verlag, Berlin Heidelberg.

Llorens L, Peñuelas J, Emmett B (2002) Developmental instability and gas exchange responses of a heathland shrub to experimental drought and warming. Int. J. Plant Sci. 163:959-967.

McCree KJ (1986) Measuring the whole-plant daily carbon balance. Photosynthetica 20:82-93.

Medrano H, Escalona JM, Bota J, Gulías J, Flexas J (2002) Regulation of photosynthesis of $\mathrm{C} 3$ plants in response to progressive drought: stomatal conductance as a reference parameter. Ann. Bot. 89:895-905.

Møller AP, Swaddle JP (1997) Asymmetry, Developmental Stability, and Evolution. Oxford University Press, Oxford.

Nilsen ET, Orcutt DM (1996) The physiology of plants under stress: abiotic factors. John Wiley, New York.

Nobel PS (1999) Physicochemical and environmental plant physiology. Academic Press, San Diego.

Otronen M, Roselund HM (2001) Morphological asymmetry and chlorophyll fluorescence in Scots pine (Pinus sylvestris): responses to variation in soil moisture, nutrients and defoliation. Ann. Bot. Fennici 38:285-294.

Palmer AR (1994) Fluctuating asymmetry analyses: a primer. In: Markow TA (ed) Developmental Instability: Its Origins and Evolutionary Implications, pp.335-364. Kluwer, Dordrecht.

Palmer AR, Strobeck C (1986) Fluctuating asymmetry: measurement, analysis, patterns. Annu. Rev. Ecol. Syst. 17: 391-421.

Parry MAJ, Andralojc PJ, Khan S, Lea PJ, Keys AJ (2002) Rubisco activity: effects of drought stress. Ann. Bot. 89: 833-839.

Rettig, JE, Fuller RC, Corbett, AL, Getty T (1997) Fluctuating asymmetry indicates levels of competion in an eve-aged poplar clone. Oikos 80:123-127.

Souza GM, Aidar ST, Giaveno CD, Oliveira RF (2003) Drought stability of different common bean (Phaseolus vulgaris L.) genotypes. Crop Breed. Appl. Biotechnol. 3: 203-208.

Souza GM, Aidar ST, Oliveira RF (2004a) Developmental stability and network connectance in Phaseolus vulgaris L. genotypes under water deficit. Isr. J. Plant Sci. 52:205-212.

Souza GM, Oliveira RF, Cardoso VJM (2004b) Temporal dynamics of stomatal conductance of plants under water deficit: can homeostasis be improved by more complex dynamics? Braz. Arch. Biol. Technol. 47:423-431.

Souza GM, Ribeiro RV, Pincus SM (2004c) Changes in network connectance and temporal dynamics of gas exchange in Citrus sinensis under different evaporative demands. Braz. J. Plant Physiol. 16:119-130. 